VARIABEL VOL. 1 NO. 2 (2018): 73-80

p-ISSN: 2593-302X dan e-ISSN: 2599-3038

This work is licensed under

a Creative Commons Attribution-NonCommercial 4.0 International License.

\title{
Pengaruh Metode Pembelajaran Improve terhadap Pemahaman Konsep Matematis Siswa pada Materi Sistem Persamaan Linear Tiga Variabel Kelas X SMA Negeri 4 Singkawang
}

\author{
Nurul Amala ${ }^{1}$, Mariyam ${ }^{2}$, Nindy Citroresmi Prihatiningtyas ${ }^{3}$ \\ Program Studi Pendidikan Matematika, STKIP Singkawang, Indonesia \\ saiaa.nurul@yahoo.co.id ${ }^{1}$, mariyam.180488@gmail.com ${ }^{2}$, nindy.citroresmi@gmail.com ${ }^{3}$
}

Kata Kunci:

Metode Improve, Pemahaman

Konsep Matematis, Motivasi

Belajar Siswa

\begin{abstract}
ABSTRAK
Secara khusus penelitian ini bertujuan; 1) Untuk mengetahui pengaruh metode pembelajaran improve terhadap pemahaman konsep pada materi sistem persamaan linear tiga variabel; 2) Untuk mengetahui aktivitas siswa selama diterapkannya metode improve; 3) Untuk mengetahui motivasi belajar siswa setelah dilaksanakannya metode improve. Jenis penelitian ini adalah True Eksperimental dengan desain penelitian Posttest Only Control Design. Instrumen yang digunakan dalam penelitian ini adalah tes pemahaman konsep matematis siswa, lembar obsevasi aktivitas siswa, dan angket motivasi belajar siswa. Berdasarkan hasil analisis data menunjukkan bahwa: 1) Terdapat pengaruh metode pembelajaran improve terhadap pemahaman konsep matematis siswa kelas X SMA Negeri 4 Singkawang 2) aktivitas belajar siswa selama diajarkan dengan metode improve tergolong aktif; 3) Motivasi belajar siswa setelah diajarkan dengan metode improve tergolong tinggi.
\end{abstract}

\section{PENDAHULUAN}

Kemampuan pemahaman konsep matematis adalah satu di antara tujuan penting dalam pembelajaran matematika (Murizal dkk., 2012). Selain itu, National Council of Teacher Of Mathematics (NCTM, 2000) juga menyatakan bahwa visi dari matematika sekolah adalah berdasarkan pada pembelajaran matematika siswa yang disertai dengan pemahaman. Belajar matematika dengan disertai pemahaman sangat diperlukan untuk memungkinkan siswa menyelesaikan masalah lain yang akan mereka hadapi di masa yang akan datang (NCTM, 2000). Sesuai hal tersebut dalam pembelajaran matematika, pemahaman konsep matematis siswa sangat penting. Dengan pemahaman konsep siswa akan berusaha menemukan masalah dan berusaha untuk menyelesaikannya.

Pemahaman konsep merupakan faktor yang berpengaruh dalam pembelajaran matematika. Menurut Zulkardi (2003:7) mengatakan bahwa "mata pelajaran matematika menekankan pada konsep", yang artinya dalam mempelajari matematika peserta didik harus memahami konsep matematika terlebih dahulu agar dapat menyelesaikan soal-soal dan mampu mengaplikasikan pembelajaran tersebut di dunia nyata dan mampu mengembangkan kemampuan lain yang menjadi tujuan dari pembelajaran matematika. Pemahaman terhadap konsep-konsep matematika merupakan dasar untuk belajar matematika. 
Namun beberapa hasil penelitian menunjukkan bahwa pemahaman konsep masih rendah. Satu diantaranya adalah penelitian yang dilakukan Huda dan Kencana (2013) di kelas VIII SMP Negeri 30 Muaro Jambi. Dari hasil penelitian menunjukkan bahwa siswa tersebut tidak mampu memahami dengan baik bagaiman menyelesaikan soal cerita dan informasi yang relevan tentang pemahaman tersebut pada langkah-langkah soal cerita dan indikator kemampuan pemahaman yaitu mengubah soal berbentuk kata-kata ke dalam simbol, menentukan konsep-konsep yang tepat untuk digunakan dalam menyelesaikan soal, dan menerapkan konsep-konsep dalam perhitungan matematis dengan tidak lancar dan tidak. Hal ini sejalan dengan hasil prariset yang diberikan peneliti dengan tes pemahaman konsep matematis. Prariset yang dilakukan di SMA Negeri 4 Singkawang kelas XA dengan memberikan 3 soal yang memuat 3 indikator pemahaman konsep yaitu, menyatakan ulang sebuah konsep, mengklasifikasikan objek-objek menurut sifat-sifat tertentu (sesuai dengan konsepnya), dan mengaplikasikan konsep atau algoritma pada pemecahan masalah.

Dari hasil pra-riset maka dapat disimpulkan bahwa siswa masih mengalami kesulitan dalam memahami konsep. Kesulitan yang dihadapi siswa dalam memahami konsep bukan hanya pada materi persamaan kuadrat melainkan pada materi lainnya. Dilihat dari hasil wawancara dengan guru mata pelajaran matematika bahwa siswa mengalami kesulitan memahami konsep sistem persamaan linear tiga variabel, siswa masih keliru untuk mendefenisikan sistem persamaan linear tiga variabel, siswa masih mengalami kesulitan untuk mengubah soal cerita ke bentuk persamaan, siswa masih kesulitan untuk menyelesaikan soal cerita dengan menggunakan metode eliminasi, metode subsitusi dan metede eliminasi subsitusi (gabungan).

Kesulitan yang dialami siswa diakibatkan kurangnya aktivitas belajar siswa selama proses pembelajaran. Hal ini sesuai hasil studi Sumarmo (Afrilianto, 2012:194) terhadap siswa SMU, SLTP, dan guru di Kodya Bandung yang hasilnya antara lain pembelajaran matematika pada umumnya kurang melibatkan aktivitas siswa secara optimal sehingga siswa kurang aktif dalam belajar. siswa tidak berani untuk menanyakan kesulitannya dalam memahami materi maupun dalam menyelesaikan soal yang diberikan guru. Siswa sering tidak memperdulikan gurunya saat guru sedang menjelaskan materi pembelajaran, sebagian besar siswa tidak bisa menyampaikan kembali materi pembelajaran sebelumnya, serta siswa cenderung lalai mengerjakan pekerjaan rumah (PR). Pada akhir pembelajaran sebagian siswa tidak bisa mengambil kesimpulan terhadap apa yang telah dipelajari. Kenyataan tersebut menunjukkan bahwa aktivitas siswa selama pembelajaran masih rendah. Sehingga berakibat pada keberhasilan siswa dalam belajar.

Keberhasilan siswa dalam proses pembelajaran dapat dipengaruhi oleh faktor motivasi. Menurut Abdillah (2015) motivasi belajar yang tinggi dapat menunjang keberhasilan belajar, akan tetapi motivasi belajar yang rendah merupakan hambatan yang akan berakibat pada hasil belajar rendah. Berdasarkan hasil pengamatan yang dilakukan peneliti di SMA N 4 Singkawang, terdapat motivasi belajar siswa rendah di kelas $\mathrm{X}$ pada pembelajaran matematika. Hal ini dilihat pada saat siswa menerima materi pelajaran, kurangnya minat dan perhatian siswa terhadap pembelajaran, siswa tidak bertanggung jawab terhadap tugas kelompoknya dan kurang adanya reaksi yang ditunjukkan siswa terhadap stimulus yang diberikan guru.

Pembelajaran dikatakan berhasil apabila sebagian besar peserta didik terlibat secara aktif dalam kegiatan belajar mengajar. Penyebab lain rendahnya pemahaman konsep siswa, disebabkan proses kegiatan pembelajaran matematika di kelas dilakukan dengan menggunakan metode ceramah, sehingga siswa kurang diajak belajar memahami tentang konsep. Satu diantara alternatif masalah dalam masalah tersebut dengan menggunakan metode improve.

Metode improve merupakan suatu metode inovatif dalam pembelajaran matematika yang didesain untuk membantu siswa dalam mengembangkan berbagai keterampilan matematika secara optimal serta meningkatkan aktivitas siswa dalam belajar. Berdasarkan penelitian yang dilakukan Permatasari (2014) bahwa penelitian menggunakan metode improve memberikan berbedaan yang signifikan dibandingkan metode konvensional. Hal yang membedakan metode Improve dengan metode lain 
adalah dalam pembelajaran dengan metode Improve, siswa diberi pertanyaan-pertanyaan metakognitif dengan belajar berkelompok.

Alasan peneliti menggunakan metode improve siswa dikenalkan pada konsep baru, yaitu diawali dengan diberikan pertanyaan-pertanyaan metakognitif dan kemudian dilatih memecahkan masalah terkait materi, siswa juga dapat mengevaluasi materi yang telah mereka pelajari siswa juga disituasikan untuk belajar berkelompok dalam menyelesaikan masalah-masalah yang ada. Kelompok tersebut terdiri dari siswa yang heterogen, situasi belajar berkelompok yang heterogen ini dapat menonjolkan interaksi dalam kelompok seperti tanya jawab, tukar pendapat, dan debat antar siswa. Selain dari itu, belajar berkelompok mampu membuat siswa menerima siswa lain yang berkemampuan latar belakang yang berbeda.Adapun sub-sub rumusan masalah dalam penelitian ini adalah (1) Apakah terdapat pengaruh metode pembelajaran improve terhadap pemahaman konsep siswa pada materi sistem persamaan linear tiga variabel di kelas X SMA Negeri 4 Singkawang?, (2) Bagaimanakah aktivitas belajar siswa selama diterapkannya metode pembelajaran improve pada materi sistem persamaan linear tiga variabel di kelas X SMA Negeri 4 Singkawang?, (3)Bagaimanakah motivasi belajar siswa setelah diterapkannya metode pembelajaran improve pada materi sistem persamaan linear tiga variabel di kelas X SMA Negeri 4 Singkawang?.

\section{METODE PENELITIAN}

Jenis penelitian ini adalah kuantitatif eksperimen dengan desain Quasi Eksperimental dalam bentuk desain The Nonequivalent Posttest Only Control Group Design (Lestari \& Yudhanegara, 2017: 136137). Populasi dalam penelitian ini adalah seluruh siswa kelas $X$ SMA Negeri 4 Singkawang yang terdiri dari 3 kelas, yaitu: X IPS 1, X IPS 2, X IPS 3, Ketiga kelas tersebut tidak ada yang menjadi kelas unggulan karena setiap kelasnya memiliki rata-rata kemampuan yang relatif sama serta penyebaran siswanya juga tidak berbeda.

Teknik pengumpulan data yang digunakan dalam penelitian ini adalah sebagai berikut; a) Teknik pengukuran, teknik pengukuran yang dimaksud adalah tes kemampuan pemahaman konsep matematis siswa yang berbentuk uraian; b) Teknik komunikasi tidak langsung, teknik komunikasi tidak langsung yang dimaksud adalah angket yang disebarkan kepada kelas eksperimen dan kelas kontrol; c) Teknik observasi langsung, teknik observasi langsung dalam penelitian ini adalah untuk mengetahui aktivitas siswa menggunakan metode pembelajaran Improve.

Instrumen pengumpulan data yang digunakan dalam penelitian ini sebagai berikut: a) Tes pemahaman konsep matematis digunakan untuk mengetahui pemahaman konsep matematis sesudah diberikan perlakuan terdiri dari 3 soal uraian; b) Lembar angket, lembar angket digunakan untuk mengetahui motivasi belajar siswa setelah diberikan perlakuan; c) Lembar observasi, lembar observasi ini digunakan untuk mengetahui aktivitas siswa menggunakan metode pembelajaran Improve yang di isi 1 orang guru dan 2 orang mahasiswa STKIP Singkawang. Sebelum tes digunakan untuk penelitian, tes pemahaman konsep diuji cobakan terlebih dahulu di SMA Negeri 2 Singkawang untuk mengetahui kevalidan, reliabilitas, daya pembeda, dan tingkat kesukaran. Dari soal yang diuji cobakan soal nomor 1, 2 dan 3 adalah soal yang valid dengan reliabilitas yang sedang. Berdasarkan analisis tingkat kesukaran soal nomor 1 termasuk dalam kategori sukar sedangkan soal nomor 2 dan 3 termasuk dalam kategori sedang. Selanjutnya berdasarkan daya pembeda soal nomor soal 1, 2 dan 3 memiliki daya pembeda baik. Jadi, semua soal digunakan untuk penelitian.

Teknik analisis data yang digunakan untuk menjawab sub rumusan masalah dalam penelitian adalah sebagai berikut.

1) Untuk menjawab sub rumusan masalah 1 yaitu untuk mengetahui mengetahui pengaruh metode improve terhadap pemahaman konsep matematis siswa akan dilakukan langkah-langkah sebagai berikut:

a. Menentukan normalitas data menggunakan uji chi-kuadrat.

b. Menentukan homogenitas data untuk mengetahui apakah kedua kelompok sampel mempunyai varians yang sama (homogen) atau tidak. 
VARIABEL Vol. 1 No. 2 (2018)

Page: $73-80$

c. Jika data yang dianalisis berdistribusi normal dan homogen, maka akan dilakukan pengujian hipotesis dengan statistik parametris $t$-test dua sampel independen.

d. Selanjutnya untuk mengetahui pengaruh metode improve terhadap pemahaman konsep matematis siswa digunakan rumus Effect Size, seperti pada persamaan (1) dengan kriteria pada Tabel 1.

$$
E S=\frac{\overline{Y e}-\overline{Y c}}{S c}
$$

Keterangan:

ES $=$ Effect Size

$\overline{Y e}=$ rata-rata kelas eksperimen

$\overline{Y c}=$ rata-rata kelas kontrol

$S c=$ standar deviasi kelas kontrol

Tabel 1. Kriteria Effect Size Mulyatiningsih (Sumarni,2014)

\begin{tabular}{cc}
\hline Effect Size & Kriteria \\
\hline$E s<0,2$ & Rendah \\
$0,2<$ Es $<0,8$ & Sedang \\
$E s \geq 0,8$ & Tinggi \\
\hline
\end{tabular}

Kriteria effect size yang diharapkan dalam penelitian ini berada pada kriteria sedang dan tinggi.

2) Untuk menjawab permasalahan yang ke-2 akan dilihat dari aktivitas belajar siswa selama proses pembelajaran dengan menggunakan statistik deskriftif. Langkah-langkah yang dilakukan untuk menghitung aktivitas siswa sebagai berikut.

a. Menghitung banyaknya siswa yang mengikuti setiap langkah dalam pembelajaran.

b. Menghitung presentase frekuensi aktivitas belajar siswa tiap indikator/kategori.

c. Menghitung presentase total aktivitas belajar siswa

d. Mengkriteriakan hasil presentase aktivitas belajar siswa. Adapun kriteria aktivitas siswa dapat dilihat pada Tabel 2.

Tabel 2. Kriteria Aktivitas Belajar Siswa (Arikunto:2006)

\begin{tabular}{cc}
\hline $\begin{array}{c}\text { Frekuensi aktivitas } \\
\text { belajar siswa (\%) }\end{array}$ & Kriteria \\
\hline $0<\mathrm{A} \geq 20$ & Sangat kurang aktif \\
$20<\mathrm{A} \geq 40$ & Kurang aktif \\
$40<\mathrm{A} \geq 60$ & Cukup aktif \\
$60<\mathrm{A} \geq 80$ & Aktif \\
$80<\mathrm{A} \geq 100$ & Sangat aktif \\
\hline
\end{tabular}

Kriteria aktivitas siswa yang diharapkan pada penelitian ini berada pada kategori aktif dan sangat aktif.

3) Untuk menjawab permasalahan yang ke-3 yaitu untuk mengetahui motivasi siswa setelah diterapkannya metode improve maka akan dianalisis perolehan skor setiap siswa yang akan dianalisis secara deskriptif dengan menggunakan presentase motivasi belajar siswa.

Untuk perhitungan motivasi siswa per individu menggunakan rumus pada Persamaan (2)

$$
P=\frac{S}{N} \times 100 \%
$$


Keterangan:

$\mathrm{P}=$ presentase skor

$\mathrm{S}=$ skor yang diperoleh

$\mathrm{N}$ = banyaknya pernyataan

Untuk menghitung motivasi siswa secara indikator menggunakan rumus pada persamaan (3)

$$
P=\frac{\text { jumlah } \text { skor }}{4 \times \text { banyak siswa }} \times 100 \%
$$

Berdasarkan perhitungan presentase motivasi belajar siswa diatas, maka kriteria presentase motivasi belajar siswa dapat dilihat pada Tabel (3).

Tabel 3. Kriteria Motivasi Belajar Siswa Arikunto:2006)

\begin{tabular}{cc}
\hline Presentase $(\%)$ & Kriteria \\
\hline $81,25<\mathrm{P} \leq 100$ & Sangat tinggi \\
$62,50<\mathrm{P} \leq 81,25$ & Tingggi \\
$43,75<\mathrm{P} \leq 62,50$ & Rendah \\
$25 \leq \mathrm{P} \leq 43,75$ & Sangat rendah \\
\hline
\end{tabular}

Kriteria motivasi siswa yang diharapkan pada penelitian ini berada pada kategori tinggi dan sangat tinggi.

\section{HASIL DAN PEMBAHASAN}

Hasil perhitungan uji normalitas pada kelompok eksperimen, diperoleh harga $x_{\text {hitung }}^{2}=6,967$ sedangkan dari tabel kritis uji chi-kuadrat diperoleh $x_{\text {tabel }}^{2}$ untuk jumlah sampel 24 dan banyak kelas 6 pada taraf signifikan $\alpha=5 \%$ adalah 7,815 diperoleh $x_{\text {hitung }}^{2} \leq x_{\text {tabel }}^{2}(6,969<7,815)$ maka $H_{0}$ diterima, artinya data yang terdapat pada kelompok eksperimen berasal dari popolasi yang berdistribusi normal. Data selengkapnya dapat dilihat pada lampiran B-7. Sedangkan pada hasil perhitungan uji normalitas pada kelompok kontrol, diperoleh harga $x_{\text {hitung }}^{2}=5,22$ sedangkan dari tabel kritis uji chi-kuadrat diperoleh $x_{\text {tabel }}^{2}$ untuk jumlah sampel 23 dan banyak kelas 6 pada taraf signifikan $\alpha=5 \%$ adalah 7,815 diperoleh $\quad x_{\text {hitung }}^{2} \leq x_{\text {tabel }}^{2}(5,217<7,815)$, maka $H_{0}$ diterima, artinya data yang terdapat pada kelompok kontrol berasal dari popolasi yang berdistribusi normal.

Selanjutnya dilakukan uji homogenitas untuk mengetahui apakah kelas eksperimen dan kelas kontrol homogen atau tidak. Hasil analisis uji homogenitas yang dilakukan dengan data posttest pada kelas eksperimen dan kelas kontrol.Hasil perhitungan untuk kelompok eksperimen diperoleh varians = 262,91 dan untuk kelompok kontrol diperoleh varians 240,37, sehingga diperoleh $F_{\text {hitung }}=1,09$. Dari tabel distribusi $\mathrm{F}$ dengan taraf signifikan $\alpha=5 \%$ dan dk pembilang $=23$ dan dk penyebut $=22$, diperoleh $F_{\text {tabel }}=2,00$ karena $F_{\text {hitung }}<F_{\text {tabel }}=(100<200)$ maka $H_{0}$ diterima atau dengan kata lain varians kedua populasi homogen.

Dari analisis data yang telah dilakukan diketahui bahwa data posttest dari kelas eksperimen dan kelas kontrol berdistribusi normal dan homogen. Langkah selanjutnya adalah menguji perbedaan antara nilai posttest pada kelas kontrol dengan posttest kelas eksperimen menggunakan rumus atau uji independent t sampel. Sehingga diperoleh nilai $t_{\text {hitung }}$ yaitu 2,63 lebih besar dari $t_{\text {tabel }}$ yaitu 2,05 artinya $\mathrm{H}_{0}$ ditolak sedangkan Ha diterima, maka dapat ditarik kesimpulan bahwa terdapat perbedaan pemahaman konsep 
VARIABEL Vol. 1 No. 2 (2018)

Page: $73-80$

matematis siswa yang diajarkan menggunakan metode improve dan yang diajarkan menggunakan model langsung.

Selanjutnya untuk melihat besaran pengaruh metode improve terhadap pemahaman konsep matematis siswa maka digunakan rumus Effect Size. Adapun hasil perhitungan Effect Size dapat dilihat pada Tabel 4 .

Tabel 4. Hasil Perhitungan Effect Size

\begin{tabular}{ccccc}
\hline Kelas & Nilai Rata-Rata & Standar Deviasi Kontrol & ES & Keterangan \\
\hline Eksperimen & 63,92 & 15,50 & 0,79 & Tinggi \\
Kontrol & 51,74 & &
\end{tabular}

Dari Tabel 4 dapat dilihat bahwa nilai Effect Size sebesar 0,79 dengan kriteria tinggi. Dari hasil perhitungan Effect Size tersebut menunjukkan bahwa pembelajaran dengan metode improve memberikan pengaruh yang positif terhadap pemahaman konsep matematis siswa. Maka dapat disimpulkan bahwa metode improve memberikan pengaruh yang tinggi terhadap pemahaman konsep matematis siswa. Pembelajaran dengan metode improve memberikan kesempatan kepada siswa untuk terlibat langsung dalam proses pembelajaran. Hal ini sejalan dengan pendapat Purnamadewi (2013) rata-rata hasil belajar dengan menggunakan metode improve lebih baik daripada rata-rata hasil belajar siswa pada pembelajaran langsung. Selanjutnya untuk mengetahui hasil dari perhitungan aktivitas siswa dapat dilihat pada Tabel 5.

Tabel 5. Perhitungan Aktivitas Siswa

\begin{tabular}{lcccc}
\hline \multicolumn{1}{c}{ Indikator } & Pertemuan I & Pertemuan II & Rata-Rata & $\begin{array}{c}\text { Rata-Rata } \\
\text { Keseluruhan }\end{array}$ \\
\hline \multirow{2}{*}{ Visual activities } & $67,7 \%$ & $68,8 \%$ & $68,2 \%$ & \\
& Aktif & Aktif & Aktif & \\
Oral activities & $57,6 \%$ & $68,1 \%$ & $62,8 \%$ & \\
Listening & Cukup aktif & Aktif & Aktif & $68,8 \%$ \\
activities & $76,0 \%$ & $80,9 \%$ & $78,5 \%$ & Aktif \\
Writing activities & Aktif & Sangat aktif & Aktif & \\
& $64,2 \%$ & $67,4 \%$ & $65,8 \%$ & \\
\hline
\end{tabular}

Berdasarkan hasil observasi pengamatan aktivitas siswa, secara umum peneliti sudah melaksanakan serangkaian kegiatan dengan menggunakan metode improve pada materi sistem persamaan linear tiga variabel dengan baik.

Dalam penelitian ini siswa menunjukkan sikap yang aktif selama pembelajaran dengan metode improve hal ini ditunjukkan presentase aktivitas siswa 68,8\%. Hal yang menyebabkan presentase aktivitas siswa aktif karena, pada pembelajaran dengan metode improve siswa membaca Lembar Kerja Siswa yang diberikan guru, siswa melihat dan mengamati kelompok lain yang sedang presentasi di depan kelas, siswa bertanya dengan guru jika ada yang belum mengerti, siswa mengemukakan pendapatnya dan membuat kesimpulan, siswa mengikuti interuksi yang diberikan guru, siswa mendengarkan pendapat yang dikemukakan oleh temannya, siswa mengerjakan soal yang tertera pada lembar kerja siswa, dan siswa menulis tugas individu yang diberikan guru.

Hal tersebut didukung oleh Hamdani (2011: 201) yang menyatakan bahwa aktivitas belajar merupakan hal yang sangat penting bagi siswa, karena memberikan kesempatan kepada siswa untuk bersentuhan dengan obyek yang sedang dipelajari seluas mungkin, karena dengan demikian proses kontruksi pengetahuan akan lebih baik. Berdasarkan penelitian yang dilakukan Astriana dkk. (2017:30) Aktivitas siswa selama pembelajaran menggunakan model pembelajaran kooperatif tipe TGT diperoleh berdasarkan perhitungan lembar pengamatan yang dilakukan selama pembelajaran 
VARIABEL Vol. 1 No. 2 (2018)

Page: $73-80$

berlangsung, siswa aktif sebesar $87,67 \%$, sedangkan siswa pasif sebesar $13,18 \%$. Sejalan dengan hal tersebut penelitian yang dilakukan oleh Laksono (2014:169) menunjukkan bahwa siswa tergolong aktif selama pembelajaran dengan metode improve. Selanjutnya untuk mengetahui hasil dari angket motivasi belajar siswa dapat dilihat pada Tabel 6 .

Tabel 6. Hasil Angket Motivasi Belajar Siswa

\begin{tabular}{lcc}
\hline \multicolumn{1}{c}{ Indikator } & Rata-Rata Perindikator & $\begin{array}{c}\text { Jumlah Rata-Rata } \\
\text { Keseluruhan }\end{array}$ \\
\hline $\begin{array}{l}\text { Minat dan perhatian siswa dalam } \\
\text { pembelajaran }\end{array}$ & $77,98 \%$ & \\
$\begin{array}{l}\text { Keikutsertaan siswa dalam diskusi } \\
\text { kelompok }\end{array}$ & $78,13 \%$ & \\
$\begin{array}{l}\text { Respon yang ditunjukkan siswa } \\
\text { terhadap materi yang akan }\end{array}$ & (Tinggi) & \\
dipelajari & $75 \%$ & $78,43 \%$ \\
Reaksi yang diberikan siswa & Tinggi \\
terhadap stimulus yang diberikan & $80,21 \%$ & \\
guru & (Tinggi) & \\
Rasa senang dan puas siswa & $78,39 \%$ & \\
dalam mengerjakan tugas-tugas & (Tinggi) & \\
yang diberikan &
\end{tabular}

Pada akhir proses pembelajaran dengan metode improve siswa diberikan angket motivasi untuk mengetahui motivasi belajar siswa selama mengikuti pembelajaran. Peniliaian motivasi siswa yaitu, minat dan perhatian siswa dalam pembelajaran metode improve, keikutsertaan siswa dalam diskusi kelompok, respon siswa terhadap materi yang akan dipelajari, rasa senang dan puas siswa dalam mengerjakan tugas-tugas yang diberikan. Berdasarkan perhitungan hasil angket motivasi belajar siswa diperoleh hasil persentase $78,43 \%$ dengan kriteria tinggi,. dengan demikian dapat dikatakan bahwa sebagian besar siswa memiliki motivasi yang tinggi terhadap pembelajaran matematika dengan menggunakan metode improve pada materi sistem persamaan linear tiga variabel.

Menurut Sardiman (Susilo dan Khabibah, 2012) motivasi belajar adalah keseluruhan daya penggerak di dalam diri siswa yang menimbulkan kegiatan-kegiatan belajar, yang menjamin kelangsungan dari kegiatan belajar dan yang memberikan arah pada kegiatan belajar, sehingga tujuan yang dikehendaki oleh subjek belajar itu dapat tercapai. Dalam penelitian ini yang menjadi daya penggerak di dalam diri siswa yang menimbulkan kegiatan belajar adalah siswa siap menerima materi yang akan dipelajari, siswa saling membantu temannya yang mengalami kesulitan, dan siswa merasa puas apabila siswa dapat menyelesaikan tugas-tugas yang diberikan.

\section{KESIMPULAN}

Berdasarkan hasil penelitian yang dilaksanakan mengenai pengaruh metode pembelajaran improve terhadap pemahaman konsep matematis siswa pada materi sistem persamaan linear tiga variabel kelas $\mathrm{X}$ SMA Negeri 4 Singkawang, maka dapat disimpulkan bahwa, terdapat pengaruh metode pembelajaran improve terhadap pemahaman konsep matematis siswa pada materi sistem persamaan linear tiga variabel kelas X dengan besaran pengaruh Effect Size sebesar = 0,79 yang berada pada kriteria sedang, aktivitas siswa selama diterapkannya metode pembelajaran improve berada dalam kriteria aktif dan Motivasi belajar siswa selama diterapkannya metode pembelajaran improve berada dalam kriteria tinggi. 


\section{VARIABEL Vol. 1 No. 2 (2018) \\ Page: $73-80$}

\section{DAFTAR PUSTAKA}

Abdillah, H. M. (2015). Pengaruh Motivasi Belajar Terhadap Prestasi Belajar Siswa Mata Pelajaran PAI Kelas VIII di SMP Negeri2 Sumbergempol Tulungagung Tahun Pelajaran 2014/2015. Skripsi. Tulungagung: IAIN Tulungagung. Tidak Dipublikasikan.

Afrilianto, Muhammad. (2012). Peningkatan Pemahaman Konsep dan Kompetensi Strategis Matematis Siswa SMP dengan Pendekatan Metaphorical Thinking. Jurnal STKIP Siliwangi Bandung, 1(2), 192-202.

Arikunto, S. (2006). Prosedur Penelitian Suatu Pendekatan Praktek. Jakarta: PT. Rineka Cipta.

Astriana, M., Murdani, E., \& Mariyam. (2017). Penerapan Model Pembelajaran Kooperatif Tipe Teams Games Tournament untuk Meningkatkan Kemampuan Pemahaman Konsep Matematis Siswa pada Materi Operasi Bilangan Pecahan. Jurnal Pendidikan Matematika Indonesia, 2(1), 27-31.

Hamdani. (2011). Strategi Belajar Mengajar. Bandung: Pustaka Setia.

Huda, N., \& Kencana, A. G. (2013). Analisis Kesulitan Siswa Berdasarkan Kemampuan Pemahaman dalam Menyelesaikan Soal Cerita pada Materi Kubus dan Balok di Kelas VIII SMP Negeri 30 Muaro Jambi. Prosiding Semirata FMIPA Universitas Lampung, Jambi.

Laksono, P. R. (2014). Penerapan Pembelajaran dengan Metode Improve pada Materi Pertidaksamaan di Kelas X-B SMAN 1 Kaumang Tulungagung. Jurnal ilmiah dapat dilihat http://www.scribd.com/doc/236461053/penerapan-pembelajaran-dengan-metode-improvepada-materi-pertidaksamaan-di-kelas-X-B-SMAN-Kaumang-Tulungagung\#download (diakses 18 November 2016)

Lestari, K. E., \& Yudhanegara, M. R. (2017). Penelitian Pendidikan Matematika. Bandung:PT Refika Aditama.

Murizal, A., Yarman., \& Yerizon. (2012). Pemahaman Konsep Matematis dan Model Pembelajaran Quantum Teaching. Jurnal Pendidikan Matematika, 1(1), 19-23.

NCTM. (2000). Principles and Standards for School Mathematics. United States of America: The National Council of Teachers of Mathematics, Inc.

Permatasari, I. (2014). Pengaruh Metode Improve terhadap Kemapuan Berfikir Kritis Matematis Siswa. Skripsi. Jakarta: Universitas Islam Negeri Syarif Hidayatullah. Tidak Dipublikasikan.

Purnamadewi, J.A. (2013). Keefektifan Pembelajaran Metode Improve dengan Pendekatan PMRI terhadap Kemampuan Pemecahan Masalah Siswa Kelas VII Materi Segiempat. Skripsi. Semarang: Fakultas MIPA Universitas Negeri Semarang. Tidak Dipublikasikan.

Sumarni, M. L. (2014). Pengaruh Metode Role Playing terhadap Hasil Pembelajaran PKN Siswa Kelas V Sekolah Dasar. Artikel Penelitian Program Studi Pendidikan Guru Sekolah Dasar. Fakultas Keguruan dan Ilmu Pendidikan Universitas Tanjungpura. Pontianak.

Susilo, Y., \& Khabibah, S. (2013). Peningkatan Motivasi Belajar Siswa melalui Model Pembelajaran Kooperatif Tipe Numbered Head Together (NHT) Materi Ajar Perbandingan dan Fungsi Trigonometri pada Siswa Kelas X. Jurnal Jurusan Matematika, Fakultas MIPA, Universitas Negeri Surabaya.

Zulkardi. (2003). Pendidikan Matematika di Indonesia: Beberapa Permasalahan dan Upaya Penyelesaiannya. Palembang: UNSRI. 